\title{
Effect of Omission of Machine Stripping on Milk Production and Parlor Throughput in East Friesian Dairy Ewes
}

\author{
B. C. McKusick, ${ }^{\star}$ D. L. Thomas, ${ }^{*}$ and Y. M. Berger† \\ *Department of Animal Sciences \\ †Spooner Agricultural Research Station \\ University of Wisconsin-Madison, Madison 53706
}

\section{ABSTRACT}

Due to the large cisternal storage capacity and nonvertical teat placement in most dairy ewes, machine stripping is commonly performed to remove milk not obtained by the machine. However, stripping requires individual manual intervention, lengthens the milking routine, and could inadvertently lead to overmilking of other ewes in the parlor. The objective of the present experiment was to estimate the effect of omission of machine stripping on milk production and parlor throughput. East Friesian crossbred dairy ewes that had been machine milked and stripped twice daily from d 0 to 79 postpartum, were randomly assigned to two stripping treatments for the remainder of lactation: normal stripping $(\mathrm{S}, \mathrm{n}=24)$, or no stripping (NS, $\mathrm{n}=$ $24)$. The NS ewes yielded $14 \%$ less commercial milk during the experiment, but had similar lactation length, milk composition, and somatic cell count compared to $\mathrm{S}$ ewes. Average machine milk yield (amount of milk obtained without manual intervention) tended to be greater for NS compared to S ewes. Average machine-on time for $\mathrm{S}$ ewes was longer than for NS ewes because of stripping, which may have resulted in overmilking of many ewes in the S group. Results from a milking simulation indicated that parlor throughput would increase by $33 \%$, and overmilking would not occur when stripping was omitted from the milking routine. These results collectively suggest that residual milk left in the udder as a result of omission of machine stripping does not negatively influence milk quality and the loss in commercial milk yield could be compensated for by improved parlor throughput.

(Key words: dairy ewe, East Friesian, machine stripping, parlor throughput)

Abbreviation key: $\mathbf{N S}=$ no stripping treatment, $\mathbf{S}=$ stripping treatment.

Received May 9, 2002.

Accepted July 3, 2002.

Corresponding author: B. C. McKusick; e-mail: brett.mckusick@ orionpharma.com.

\section{INTRODUCTION}

One of the most important goals of mechanized milking is to obtain the maximum amount of milk that is rich in total solids, in the shortest amount of time, without manual intervention. The use of machine and/ or hand stripping is not common in dairy cattle, and it is generally not practiced in dairy ewes in the Roquefort region of France, where the greatest percentage of dairy ewes in the world are machine milked (Barillet and Bocquier, 1993). Conversely, at present, machine stripping still remains part of the normal milking routine to obtain milk not removed by the machine for most sheep dairies in other countries, primarily due to the large cisternal storage capacity and nonvertical teat placement of dairy ewes. However, stripping requires individual manual intervention, lengthens the milking routine, and could inadvertently lead to overmilking of other ewes in the parlor.

Depending on breed, udder conformation, stage of lactation, parity, and machine vacuum level, the percentage of total milk obtained during machine stripping in dairy ewes generally ranges between 10 and 30\% (Labussière, 1984) and can sometimes be as high as 60\% (Sagi and Morag, 1974). Stripping volume may also depend on milk ejection because oxytocin concentrations have been shown to rise in response to stripping (Bruckmaier et al., 1997), and therefore some ewes could be habituated to manual massage for milk letdown, which makes stripping obligatory for complete milk removal. No reports exist on whether or not this habituation could be overcome by omitting machine stripping. Evaluations of the effect of omission of machine and/or hand stripping on milk production have been conducted with some dairy sheep breeds such as the Lacaune, Sarda, and Manchega (Bosc et al., 1967; Ricordeau and Labussière, 1968; Labussiére et al., 1984; Molina et al., 1991); however, there is relatively little information on the subject for East Friesian dairy ewes, a breed with large cisternal size (Bruckmaier et al., 1997; McKusick et al., 1999).

The objectives of the present experiment were to compare the effect of stripping or omission of stripping, 
for East Friesian dairy ewes with initially low or high stripping percentage, on milk production, milk composition, and lactation length during mid- to late lactation. A secondary objective was to utilize the results of the present experiment to estimate the economic impact that stripping or omission of stripping, with one or two milkers, would have on parlor throughput and incidence of overmilking. Our hypothesis is that the milking routine for the East Friesian could be simplified by the omission of machine stripping and improvements could be made in parlor throughput and incidence of overmilking. Furthermore, we hypothesize that the amount of milk obtained by the machine without or before stripping would be greater for ewes that had adapted to a milking routine without manual udder massage.

\section{MATERIALS AND METHODS}

\section{Animals and Experimental Design}

Forty-eight multiparous East Friesian crossbred dairy ewes (50 to 75\% East Friesian and 25 to 50\% Dorset, Polypay, and/or Rambouillet) were studied from d 80 to the end of lactation at the Spooner Agricultural Research Station of the University of Wisconsin-Madison during the summer of 2000 . Ewes with symmetrical udders, similar average milk production $(2.25 \pm 0.43$ $\mathrm{kg} / \mathrm{d}$, mean $\pm \mathrm{SD})$ and stage of lactation $(79 \pm 10 \mathrm{~d}$, mean $\pm \mathrm{SD}$ ) were chosen from the main dairy flock of 350 ewes that are machine milked and machine stripped twice daily; prestimulation was not performed before milking. All ewes in the experiment had been weaned from their lambs at approximately $24 \mathrm{~h}$ postpartum. On two consecutive days during the week before the experiment, udder morphology traits were scored subjectively and measured externally with a ruler, and individual morning milk production (machine milk and machine stripped milk) was recorded. Average (mean \pm SD) udder circumference, cistern height, teat placement score, and stripping percentage were $44.9 \pm 3.5 \mathrm{~cm}, 2.54 \pm 0.97 \mathrm{~cm}$, and $5.55 \pm 1.65$ (scale of 1 to $9,1=$ horizontal, $5=45^{\circ}, 9=$ vertical), and $15.8 \pm 7.3 \%$, respectively. Ewes were blocked into two groups on their average percentage of stripped milk $(\leq 15 \%$ or $>15 \%$ ), and randomly assigned within block to two stripping treatments for the remainder of lactation: normal stripping $(\mathbf{S}, \mathrm{n}=24)$, or no stripping $(\mathbf{N S}, \mathrm{n}=$ 24). Treatment groups were housed separately in two neighboring pens and fed a 16\% CP concentrate in the parlor and alfalfa hay in the pens.

\section{Data Collection}

Machine milking took place at 0600 and $1800 \mathrm{~h}$ in a $2 \times 12$ high-line Casse system milking parlor with six milking units and two milkers. The milking machine (Alfa Laval Agri Inc., Kansas City, MO) was set to provide 180 pulsations per minute in a 50:50 ratio with a vacuum level of $36 \mathrm{kPa}$. Individual ewe milk production (machine milk and stripped milk), milking time, and milk flow emission kinetics were recorded during a morning milking every $20 \mathrm{~d}$ with milk collection jars and a data logger designed for recording milk flow (Le Du and Dano, 1984). For S ewes, stripping commenced within $5 \mathrm{~s}$ after the cessation of machine milk flow $(<100$ $\mathrm{ml} / \mathrm{min}$ ) and stripping ended when the milker deemed it necessary to remove the teat cups; both times were noted electronically with a data logger. Machine stripping was performed by the same milker by first lifting the udder at the intramammary groove, while applying gentle downward traction to the teat cups, and then by brief manual massage of both udder halves to remove the remaining milk. Machine milk yield and time, and stripping yield and time were calculated from the milk flow data recorded by the data logger. Additionally, milk production was recorded and milk samples were collected monthly throughout the entire lactation. Milk composition analyses for percentage of fat and protein, and Fossomatic SCC were performed by a Wisconsin State certified laboratory. An estimation of milk production and percentages of milk fat and protein within a lactation period were calculated according to Thomas et al. (2000). Somatic cell count was transformed to logarithms of base ten. Ewes were removed from the experiment and dried off when their daily milk production on a test day fell below $0.4 \mathrm{~kg} / \mathrm{d}$.

\section{Parlor Throughput Simulation}

Parlor throughput time, milking efficiency, frequency of overmilking, and relative economic returns for the two treatments were estimated from a simulated milking system in which ewes would be milked in groups of 12 ewes in a $1 \times 12$ Casse system parlor with 6 milking units and one or two milkers. Fixed times, which had been measured previously in this flock for a group of 12 ewes, included: parlor entry time (45 s), parlor exit time (includes teat-dipping, $30 \mathrm{~s}$ ), and the time to remove the teat cups and replace them on a neighboring ewe $(7$ s/ewe). All fixed times are in agreement with those cited for other dairy ewes (Le Du, 1984). Milking procedure time for a group of 12 ewes was calculated by simulation using the results from the present experiment for individual $\mathrm{S}$ and NS ewes, respectively: machine milking time (72 and $79 \mathrm{~s}$ ), stripping time (18 and $0 \mathrm{~s}$ ), and machine-on time (90 and $79 \mathrm{~s}$ ) (see Table 1). Ewes in the simulation were numbered 1 through 12 as they were in order in the stanchions. With one milker, teat cups would be placed in order on ewes 1 , 
Table 1. Least squares means \pm SEM for morning machine milking and machine stripping traits for ewes within the two treatment groups immediately before and during the experiment.

\begin{tabular}{llcl}
\hline Factor & Treatment $^{1}$ & Pre-experiment & Experiment \\
\hline Machine milk, kg & $\mathrm{S}$ & $1.19 \pm 0.06$ & $0.63 \pm 0.02$ \\
& $\mathrm{NS}$ & $1.13 \pm 0.06$ & $0.68 \pm 0.02$ \\
Machine stripped milk, kg & $\mathrm{S}$ & $0.20 \pm 0.01$ & $0.18 \pm 0.01$ \\
& $\mathrm{NS}$ & $0.21 \pm 0.01$ & $\ldots$ \\
Machine stripped milk, \% & $\mathrm{S}$ & $15.1 \pm 1.2$ & $23.6 \pm 1.0$ \\
& $\mathrm{NS}$ & $16.5 \pm 1.2$ & $\ldots$ \\
Total morning milk, kg & $\mathrm{S}$ & $1.39 \pm 0.06$ & $0.80 \pm 0.02^{\mathrm{a}}$ \\
& $\mathrm{NS}$ & $1.34 \pm 0.06$ & $0.68 \pm 0.02^{\mathrm{b}}$ \\
Machine milking time, s & $\mathrm{S}$ & $114.5 \pm 5.8$ & $71.7 \pm 2.4$ \\
& $\mathrm{NS}$ & $115.1 \pm 5.8$ & $78.7 \pm 2.4$ \\
Machine stripping time, s & $\mathrm{S}$ & $20.9 \pm 2.4$ & $17.5 \pm 0.7$ \\
& $\mathrm{NS}$ & $23.1 \pm 2.0$ & $\ldots$. \\
Machine-on time, s & $\mathrm{S}$ & $130.5 \pm 8.3$ & $89.1 \pm 2.4^{\mathrm{c}}$ \\
& $\mathrm{NS}$ & $136.4 \pm 6.9$ & $78.7 \pm 2.4^{\mathrm{d}}$ \\
\hline
\end{tabular}

${ }^{\mathrm{a}, \mathrm{b}}$ Means for a factor within a column with different subscripts $\operatorname{differ}(P<0.05)$.

${ }^{\mathrm{c}, \mathrm{d}}$ Means for a factor within a column with different subscripts differ $(P<0.10)$.

${ }^{1}$ Treatment from d 80 to the end of lactation: $\mathrm{S}=$ machine milking and machine stripping $(\mathrm{n}=24)$; $\mathrm{N}=$ machine milking with no machine stripping $(\mathrm{n}=24)$.

$3,5,7,9$, and 11 , followed by removal no earlier than the average milking time, and then placement in order on ewes $2,4,6,8,10$, and 12 . With two milkers, the first milker would place teat cups on ewes 1,3 , and 5 followed by placement on ewes 2,4 , and 6 . Simultaneously, the second milker would place teat cups on ewes 7,9 , and 11 followed by placement on ewes 8,10 , and 12. Overmilking of an individual ewe was noted when the machine-on time exceeded that of the average milking time. Milk was sold for $\$ 1.32 / \mathrm{kg}$. Additional labor and expenses, relative to the S system and one milker, included $\$ 9.00 / \mathrm{h}$ for labor and $\$ 0.37 /$ ewe per milking for individual ewe purchase price, management, and feed costs as calculated previously within this experimental flock (Berger, 1998).

\section{Statistical Analyses}

Least squares means analysis of variance was conducted with the general linear models procedure of SAS (1999). Preexperimental, experimental, and total lactation data were analyzed separately with the following model: block (preexperimental stripping percentage: $\leq 15 \%$ or $>15 \%$ ), treatment (NS or S), block $\times$ treatment, ewe within block $\times$ treatment, and residual error. Preexperimental SCC and percentage of milk fat were used as a continuous covariable in the analyses of SCC and percentage of milk fat, respectively, during the experimental period and for the entire lactation. Further analyses of data during the experimental period only were analyzed with a split plot on time analysis for measurements taken every $20 \mathrm{~d}$ during the morning milking. The model included the following main plot effects: block, treatment, block $\times$ treatment, and ewe within block $\times$ treatment; and the subplot effects of time (d$100,120,140$, and 160), two-way interactions with time, and residual error. Least squares means for treatment, block, and block $\times$ treatment were tested for significance against ewe within block $\times$ treatment as the error term. Time and all interactions with time were tested for significance against residual error. Reports on parlor throughput, economic returns, and frequency of overmilking were not analyzed statistically and are only provided to give the reader a reasonable estimate from a hypothetical simulation.

\section{RESULTS}

\section{Milk Production}

Lactation period data are summarized in Table 2 and Figure 1. Milk yield for NS ewes during the experimental period was $14 \%$ less $(-17.1 \mathrm{~kg})$ than that for S ewes; however, overall lactation yields were not statistically different. Test-day milk yield for $\mathrm{S}$ ewes was consistently higher, compared to NS ewes, through d 140 of the experimental period. Both treatment groups lactated for a similar number of days and had similar overall milk protein content. After correcting for slight differences in percentage of milk fat and SCC during the preexperimental period, milk fat content and SCC were not different between treatment groups for the entire lactation. Block $\times$ treatment interaction was not a significant source of variation for any lactation trait.

Morning machine milking and stripping data are summarized in Table 1. Machine milk yield (the amount 
Table 2. Least squares means \pm SEM for lactation traits of ewes within the two treatment groups prior to and during the experiment, and for the entire lactation.

\begin{tabular}{llccl}
\hline & & \multicolumn{2}{c}{ Lactation period } & \\
\cline { 3 - 4 } Factor & Treatment $^{1}$ & Preexperiment & Experiment & \multicolumn{1}{l}{$\begin{array}{l}\text { Entire } \\
\text { lactation }\end{array}$} \\
\hline Lactation period length, d & $\mathrm{S}$ & $79.4 \pm 2.1$ & $102.6 \pm 2.3$ & $182.0 \pm 3.4$ \\
& $\mathrm{NS}$ & $78.4 \pm 2.1$ & $104.5 \pm 2.3$ & $183.0 \pm 3.4$ \\
Milk yield, kg/ewe & $\mathrm{S}$ & $177.6 \pm 6.8$ & $122.7 \pm 4.8^{\mathrm{a}}$ & $300.2 \pm 10.5$ \\
& $\mathrm{NS}$ & $175.2 \pm 6.8$ & $105.6 \pm 4.8^{\mathrm{b}}$ & $280.8 \pm 10.5$ \\
Average milk yield, kg/d & $\mathrm{S}$ & $2.28 \pm 0.09$ & $1.21 \pm 0.05^{\mathrm{a}}$ & $1.67 \pm 0.06$ \\
& $\mathrm{NS}$ & $2.23 \pm 0.09$ & $1.01 \pm 0.05^{\mathrm{b}}$ & $1.53 \pm 0.06$ \\
Milk fat, \% & $\mathrm{S}$ & $5.51 \pm 0.16^{\mathrm{c}}$ & $5.71 \pm 0.10$ & $5.57 \pm 0.05$ \\
& $\mathrm{NS}$ & $5.15 \pm 0.16^{\mathrm{d}}$ & $5.73 \pm 0.10$ & $5.58 \pm 0.05$ \\
Milk protein, \% & $\mathrm{S}$ & $4.56 \pm 0.07$ & $4.91 \pm 0.07$ & $4.78 \pm 0.06$ \\
& $\mathrm{NS}$ & $4.55 \pm 0.07$ & $4.90 \pm 0.07$ & $4.77 \pm 0.06$ \\
SCC, $\log _{10}$ units & $\mathrm{S}$ & $4.72 \pm 0.08^{\mathrm{c}}$ & $4.91 \pm 0.08$ & $4.80 \pm 0.04$ \\
& $\mathrm{NS}$ & $4.52 \pm 0.08^{\mathrm{d}}$ & $4.76 \pm 0.08$ & $4.73 \pm 0.04$ \\
\hline
\end{tabular}

${ }^{\mathrm{a}, \mathrm{b}}$ Means for a factor within a column with different subscripts differ $(P<0.05)$.

${ }^{\mathrm{c}, \mathrm{d}}$ Means for a factor within a column with different subscripts differ $(P<0.10)$.

${ }^{1}$ Treatment from d 80 to the end of lactation: $\mathrm{S}=$ machine milking and machine stripping $(\mathrm{n}=24)$; NS = machine milking with no machine stripping $(\mathrm{n}=24)$.

of milk obtained without or before stripping) was higher for NS than for S ewes at all test days during the experimental period; however, only the difference at $120 \mathrm{~d}$ of lactation was statistically significant. Total morning milk yield was lower for NS than for S ewes, of which machine stripped milk accounted for $23.6 \%$ of the total milk volume for the latter. Machine milking time (the time to obtain machine milk) was not different between treatment groups; however, total machine-on time tended to be longer for S ewes than for NS ewes. Block $\times$ treatment interaction was not a significant source of variation for any machine milk or stripping trait. Machine milk emission kinetics (milk flow latency, maximum milk flow rate, average milk flow rate, time to maximum milk flow) were not different between treatment groups at any stage of lactation (data not shown). Sample statistics for milk flow traits before the experiment (d 79) are summarized in Table 3.

\section{Parlor Throughput}

Estimates of parlor throughput, milk production, relative economic returns, and frequency of overmilking are presented in Table 4 from a simulation for S and NS ewes milked with one or two milkers. Parlor throughput was lowest when stripping was performed with only one milker, and increased with the addition of one milker or when stripping was not performed by either one or two milkers. Collectively, parlor throughput and milking efficiency increased by 31 and $13 \%$, respectively, when stripping was omitted compared with when stripping was performed. Relative receipts generated per hour were lowest for S ewes with one milker and highest for
$\mathrm{S}$ ewes with two milkers compared to NS ewes with either one or two milkers. Some degree of overmilking always occurred for $\mathrm{S}$ ewes regardless of number of milkers. Overmilking never occurred for NS ewes, even with only one milker.

\section{DISCUSSION}

\section{Milk Production}

Machine and/or hand stripping is often practiced during machine milking of dairy ewes to improve total milk yield and to avoid leaving large quantities of residual milk in the udder. However, individual machine-on time increases (Jatsch and Sagi, 1979; Fernández et al., 1997) because the udder is lifted and/or massaged by hand or the machine to remove milk trapped below the level of the teat (Jatsch and Sagi, 1979; Labussière, 1988). We have shown that when machine stripping is omitted from the milking routine during midlactation in East Friesian crossbred dairy ewes, total commercial milk available for marketing is approximately $14 \%$ less per ewe than when machine stripping is practiced. This is in agreement with the 12 to $16 \%$ reduction reported for dairy ewes (Bosc et al., 1967; Ricordeau and Labussière, 1968; Labussière et al., 1984) and the 5 to $15 \%$ reduction reported for dairy cows (Ebendorff et al., 1990). However, omission of machine stripping did not reduce lactation length or deleteriously affect milk composition or milk quality, which has previously been a concern in dairy ewes (Bosc et al., 1967), dairy goats (Wilde et al., 1989), and dairy cows (Ebendorff et al., 1987). Moreover, failure to demonstrate a significant 
Table 3. Sample statistics of milk flow traits in East Friesian crossbred dairy ewes prior to the start of the experiment (d 79 in lactation).

\begin{tabular}{llcc}
\hline & & \multicolumn{2}{c}{ Range } \\
\cline { 3 - 4 } Factor & Mean $\pm \mathrm{SD}$ & Minimum & Maximum \\
\hline Maximum milk flow rate, L/min & $1.24 \pm 0.30$ & 0.60 & 1.90 \\
Average milk flow rate, L/min & $0.54 \pm 0.12$ & 0.22 & 0.78 \\
Milk flow latency, s & $13.1 \pm 6.7$ & 5 & 48 \\
Time of maximum flow, s & $34.3 \pm 19.1$ & 12 & 108 \\
\hline
\end{tabular}

block $\times$ treatment interaction for any lactation trait demonstrated that the loss in milk production is similar for ewes with low or high initial stripping percentage when stripping is omitted from the milking routine.

Cisternal storage volume in dairy ewes is large, comprising between 50 and $60 \%$ of the total milk volume after a normal 12-h milking interval (Marnet and

A

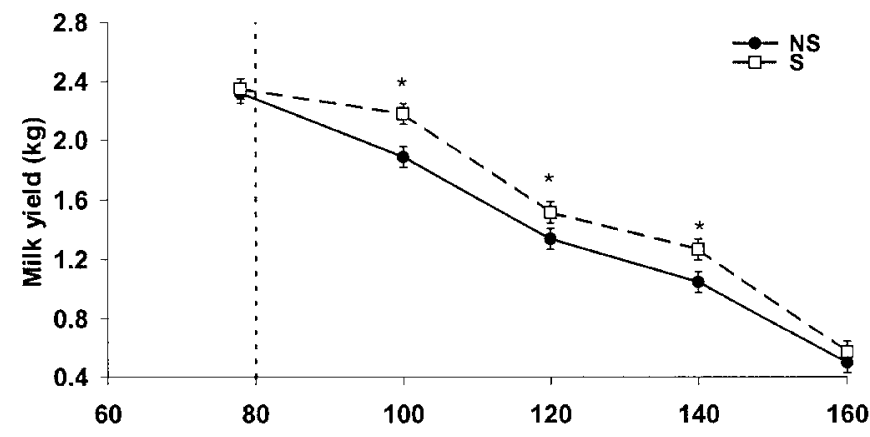

B

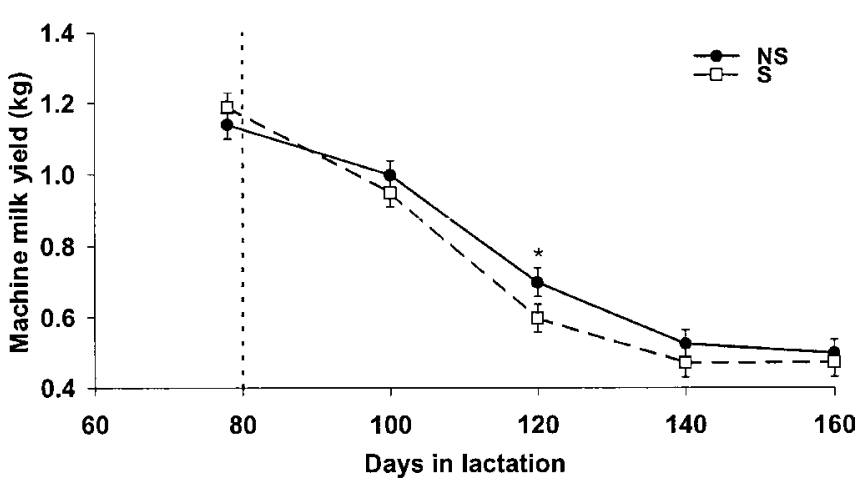

Figure 1. Test-day commercial milk yield (panel A) and morning machine milk yield (the amount of milk obtained without or prior to stripping) (panel B) for the two treatment groups: NS ewes $(\mathrm{n}=24)$ were not machine stripped from d 80 to the end of lactation; S ewes $(\mathrm{n}=24)$ were machine stripped. The dotted line indicates the start of the experiment. Data represent least squares means $( \pm$ SEM) for the treatment $\times$ time interaction. *Indicates a significant difference between treatments $(P<0.05)$.
McKusick, 2001; McKusick et al., 2002a). The East Friesian has been classified as a breed with large cisternal storage capacity (Bruckmaier et al., 1997; McKusick et al., 1999), which enables the udder to more effectively store milk between milkings (Knight and Dewhurst, 1994). A possible advantage of large cisternal storage capacity is that a higher proportion of the milk could be stored away from the alveoli, thereby reducing the concentration of a putative feedback inhibitor of lactation (Davis et al., 1998) as well as alveolar pressure due to overdistention (Labussière, 1988). This appears to be the case in the present experiment because the residual milk left behind in the udder of NS ewes had no consequences on lactation performance. This contrasts to one study in dairy goats where $100 \mathrm{ml}$ of milk (7.6\% of normal milk yield), which was purposely not removed from the udder at each milking for $24 \mathrm{wk}$ after peak lactation, caused milk yield to be reduced by $24 \%$ compared to controls (Wilde et al., 1989). The main physiologic difference between the present study and the latter is that residual milk in our study had presumably already been ejected into the cistern, and thus the putative negative feedback inhibitor of lactation that Wilde et al. (1989) discusses may not have been in contact with the alveoli.

Larger cisterns in dairy ewes have been positively correlated with more laterally horizontal teat placement (Fernández et al., 1995). One disadvantage for dairy ewes with large cisternal storage capacity is that machine stripping would be obligatory because the machine milk fraction decreases and the stripping fraction increases as the udder halves become less differentiated and teat placement is more horizontal (Sagi and Morag, 1974). This does not seem to be the case in the present experiment because the correlations between stripping percentage and external measurements of the cistern (distance between the exit of the teat and the bottom of the udder) or a subjective score for teat placement were nonsignificant (data not shown).

Milk composition was not affected by omission of machine stripping in the present experiment. Failure to demonstrate differences in milk composition, particularly in milk fat, implies that an adequate milk ejection reflex was present even though machine stripping was 
not practiced. The great majority of milk fat is stored within the alveoli between milkings (Labussière, 1988; McKusick et al., 2002a, 2002b), and active expulsion of fat from the alveoli to the cistern (milk ejection) is required for complete milk fat removal during machine milking of dairy ewes (McKusick et al., 2002a, 2002b). Additionally, the fact that machine milk yield increased (although nonsignificantly) when stripping was omitted from the milking routine may suggest that some ewes had been habituated to manual massage during at least part of the milk removal process; omission of stripping may have resulted in dishabituation of these ewes to hand contact for milk ejection. These observations are further supported by the fact that lactation lengths were similar for both treatment groups because decreased lactation persistency would be expected if ewes had retained milk in the alveoli as a result of failed milk ejection. Bruckmaier et al. (1997) found that for Lacaune ewes, oxytocin concentrations peaked at $1 \mathrm{~min}$ during machine milking and also during machine stripping; however, for East Friesian ewes, oxytocin increased above baseline levels only during machine stripping. They conclude that East Friesian ewes are more dependent on manual stimulation of the udder for complete milk removal than Lacaune ewes. The findings of the present experiment disagree with those of Bruckmaier et al. (1997) because neither a decrease in milk fat content nor in lactation length was observed when manual stimulation was not practiced during milking. It appears that the East Friesian crossbred dairy ewes in this experimental flock are well adapted to machine milking and that milk ejection and milk synthesis are not compromised by omission of stripping during mid- to late lactation.

Even though machine stripping for $\mathrm{S}$ ewes required 17.5 s/ewe of individual manual attention from the milker, overall machine-on time increased by only 10 s/ewe compared with NS ewes. This is probably due to the increase in machine milk yield, and, therefore, machine milking time, for NS ewes compared to S ewes. The average volume of milk obtained by machine stripping for S ewes corresponded to $0.18 \mathrm{~kg}$ or $23 \%$ of the total milk volume, which is consistent with other reports on dairy ewes (Labussière, 1984). Stripping volume remains constant from midlactation to the end of lactation in dairy ewes; however, stripping percentage increases as lactation progresses (Ricordeau et al., 1963; Ricordeau and Labussière, 1968) due to a relative decrease in daily milk production. Machine milking efficiency (kilograms of milk obtained per hour) is decreased when stripping is practiced because stripping increases individual milking time and increases machine-on time by $27 \%$ in the ewe (Ricordeau et al., 1963) and by 20 to $40 \%$ in the cow (Clough, 1964). The results of the present experiment would suggest that machine milking efficiency is actually improved by omission of stripping because more milk is obtained by the machine and therefore helps to explain why the loss in milk yield for NS ewes compared to S ewes is only 14\% compared with $23 \%$ (the stripping percentage of S ewes).

\section{Parlor Throughput}

Results from the present experiment were used to estimate the impact of stripping or omission of stripping with one or two milkers on parlor throughput, incidence of overmilking, and financial returns. The simulation estimated a parlor throughput of 138 ewes/h when stripping is practiced by two milkers (the normal milking procedure for this flock of dairy ewes). Estimated parlor throughput corresponded to the actual observed parlor throughput for this flock during mid- to late lactation (125 to 150 ewes/h, Berger and Thomas, 1997) and to other reports for dairy ewes (137 ewes/h, Le Du, 1984; 100 to 140 ewes/h, Billon, 1998). The results of the present simulation thus appear to be representative of the normal milking routine.

Stripping increases parlor throughput time (Ricordeau et al., 1963; Billon, 1998) and requires more labor investment (Le $\mathrm{Du}, 1984)$. The present experiment is consistent with these reports because parlor throughput, milking efficiency, and relative receipts generated per hour decreased when stripping was performed by only one milker compared with two milkers. This would be expected because the milker must give individual attention to each ewe during stripping and approximately 35 fewer ewes are milked per hour. When stripping was omitted from the milking routine, we estimated that parlor throughput would increase by 15 to 28 ewes/h with one or two milkers, respectively, compared to stripping with two milkers. We estimated that relative receipts would not differ greatly $(\$ 118.78$, $\$ 116.72$, and $\$ 123.78$, respectively) because the decrease in milk yield associated with the omission of stripping is compensated for by the additional number of ewes milked per hour. Furthermore, for a milking routine with no stripping, the addition of a second milker and extra ewes did not appear to be any more financially advantageous than using one milker.

When the milking routine included stripping, the incidence of overmilking was between 33 and $92 \%$ (4 of 12 ewes, and 11 of 12 ewes) for two or one milkers, respectively. Overmilking occurs because stripping requires the individual attention of the milker and therefore stripping for some ewes commenced well after the machine milk yield had been obtained by the machine. When stripping was omitted from the milking routine, it was estimated that overmilking would not occur $(0$ 
Table 4. Simulation of parlor throughput, milking efficiency, relative economic returns, and overmilking rate for East Friesian crossbred dairy ewes in mid- to late-lactation milked in a $1 \times 12$ Casse system parlor with or without stripping, and by one or two milkers.

\begin{tabular}{|c|c|c|c|c|}
\hline & \multicolumn{4}{|c|}{ Stripping treatment } \\
\hline & $\mathrm{S}$ & $\mathrm{S}$ & NS & NS \\
\hline No. Milkers: & 1 & 2 & 1 & 2 \\
\hline \multirow{5}{*}{$\begin{array}{l}\text { Parlor entry time },{ }^{1} \mathrm{~s} \\
\text { Milking procedure time },{ }^{1} \mathrm{~s} \\
\text { Parlor exit time },{ }^{1} \mathrm{~s} \\
\text { Parlor time },{ }^{1} \mathrm{~s} \\
\text { Parlor time },{ }^{1} \mathrm{~min}\end{array}$} & 45 & 45 & 45 & 45 \\
\hline & 344 & 237 & 207 & 186 \\
\hline & 30 & 30 & 30 & 30 \\
\hline & 419 & 312 & 282 & 261 \\
\hline & 6.98 & 5.20 & 4.70 & 4.35 \\
\hline Parlor throughput, ewes/h & 103 & 138 & 153 & 166 \\
\hline \multirow{2}{*}{$\begin{array}{l}\text { Milk yield, kg/ewe } \\
\text { Milking efficiency, kg/h }\end{array}$} & 0.80 & 0.80 & 0.68 & 0.68 \\
\hline & 82.4 & 110.4 & 104.0 & 112.9 \\
\hline \multirow{3}{*}{$\begin{array}{l}\text { Total receipts, }{ }^{2} \$ / \mathrm{h} \\
\text { Additional expenses, }{ }^{3} \$ / \mathrm{h} \\
\text { Relative receipts, }{ }^{4} \$ / \mathrm{h}\end{array}$} & 108.77 & 145.73 & 137.28 & 149.03 \\
\hline & & 21.95 & 18.50 & 32.31 \\
\hline & 108.77 & 123.78 & 118.78 & 116.72 \\
\hline Ewes overmilked, no. & $11 / 12$ & $4 / 12$ & $0 / 12$ & $0 / 12$ \\
\hline
\end{tabular}

\footnotetext{
${ }^{1}$ For a group of 12 ewes.

${ }^{2}$ Receipts from milk sold @ \$1.32/kg.

${ }^{3}$ Additional expenses relative to the $\mathrm{S}$ system with one milker: Labor costs $=\$ 9.00 / \mathrm{hr}$; ewe purchase, management, and feed costs $=\$ 0.37$ per ewe.

${ }^{4}$ Total receipts - additional expenses.
}

of 12 ewes) because the milker was no longer required to give individual attention to each ewe for the period of time required for stripping to take place. Overmilking has been shown to increase the incidence of IMI in dairy cows (Mein et al., 1986) by compromising the teat end's ability to resist bacterial penetration to the mammary gland (Peterson, 1964), resulting in decreased milk production and economic loss. Additionally, we have observed a consistent and habitual pattern in the way dairy ewes position themselves in the parlor before milking. Because the simulation estimated longer machine-on times for certain positions within the parlor (data not shown), the same ewes could be consistently overmilked from day to day. Although economic loss as a result of overmilking associated with stripping was not estimated in the simulation, it is likely that the system with one milker and omission of stripping would be even more financially advantageous than a milking routine that included stripping.

\section{CONCLUSIONS}

Omission of machine stripping in East Friesian dairy ewes during mid- and late lactation resulted in a $14 \%$ reduction in commercial milk available for marketing. However, milk composition, lactation length, and SCC were not affected. It appears that a milking routine without machine stripping improves parlor throughput and decreases the incidence of overmilking. Moreover, it is estimated that milking efficiency and financial re- turns could be improved by adding additional ewes to the flock in order to compensate for the expected loss in milk production when the milking routine is simplified to not include stripping.

\section{ACKNOWLEDGMENTS}

The authors express their gratitude to the Babcock Institute for International Dairy Research and Development (Madison, WI) who have generously supported the dairy sheep research program at the University of Wisconsin-Madison. The authors wish to thank Lori Brekenridge, Ann Stallrecht, and Richard Schlapper at the Spooner Agricultural Research Station for their committed efforts in the care and maintenance of the animals, and for their excellent help with data collection during the experiments. We are grateful for the technical assistance of Professor Pierre-Guy Marnet and Yves Dano at the Institut National de la Recherche Agronomique, Rennes, France, and we thank Pierre Billon at the Institut de L'Elevage, Le Rheu, France for the use of his milk flow data recorder.

\section{REFERENCES}

Barillet, F., and F. Bocquier. 1993. Le contexte de production des ovins laitiers en France: Principaux objectifs de recherche-développement et conditions de leur mise en æuvre. INRA Prod. Anim. $6: 17-24$.

Berger, Y. M., and D. L. Thomas. 1997. Development of the dairy sheep milking parlor at the Spooner Agricultural Research Station. Pages 24-26 in Proc. Third Great Lakes Dairy Sheep Symp., Univ. Wisc.-Madison, Dept. Anim. Sci. 
Berger, Y. M. 1998. An economic comparison between a dairy sheep and a non-dairy sheep operation. Pages 32-39 in Proc. Fourth Great Lakes Dairy Sheep Symp., Univ. Wisc.-Madison, Dept. Anim. Sci.

Billon, P. 1998. Milking parlours and milking machines for dairy ewes. Pages 18-31 in Proc. Fourth Great Lakes Dairy Sheep Symp., Univ. Wisc.-Madison, Dept. Anim. Sci.

Bosc, J., J. C. Flamant, and G. Ricordeau. 1967. Traite à la machine des brebis: Suppression de l'égouttage manuel ou remplacement par un égouttage-machine. Ann. Zootech. 16:191-202.

Bruckmaier, R. M., G. Paul, H. Mayer, and D. Schams. 1997. Machine milking of Ost-friesian and Lacaune dairy sheep: Udder anatomy, milk ejection, and milking characteristics. J. Dairy Res. 64:163-172.

Clough, P. 1964. Machine stripping: Is it really necessary? Agriculture: J. Ministry Agric. Great Br. 17:361-363.

Davis, S. R., V. C. Farr, J. A. Copeman, V. R. Carruthers, C. H. Knight, and K. Stelwagen. 1998. Partitioning of milk accumulation between cisternal and alveolar compartments of the bovine udder: relationship to production loss during once daily milking. J. Dairy Res. 65:1-8.

Ebendorff, W., K. Kram, G. Michel, and J. Ziesack. 1987. Machine stripping, milk yield and udder health: Results of long-term experiments over 4 lactations. Milchwissenschaft 42:23-25.

Ebendorff, W., J. Wallstabe, A. Kreutzer, and J. Ziesack. 1990. Effect of automatic udder stimulation and stripping on milk production and udder health of cows. Milchwissenschaft 45:299-302.

Fernández, G., P. Alvarez, F. San Primitivo, and L. F. De la Fuente. 1995. Factors affecting variation of udder traits of dairy ewes. J. Dairy Sci. 78:842-849.

Fernández, G., J. A. Baro, L. F. De la Fuente, and F. San Primitivo. 1997. Genetic parameters for linear udder traits of dairy ewes. J. Dairy Sci. 80:601-605.

Jatsch, O., and R. Sagi. 1979. Machine milkability as related to dairy yield and its fractions in dairy ewes. Ann. Zootech. 28:251-260.

Knight, C. H., and R. J. Dewhurst. 1994. Once daily milking of dairy cows: relationship between yield loss and cisternal milk storage. J. Dairy Res. 61:441-449.

Labussière, J. 1984. Etude des aptitudes laitières et de la facilité de traite de quelques races de brebis du bassin méditerranéen. Pages 730-792 in Proc. Third Symp. Mach. Milking of Sm. Rum., Valladolid, Spain.

Labussière, J., B. Benmederbel, J. F. Combaud, and F. A. De la Chevalerie. 1984. The principal milk production traits, udder morphology and milk ejection in Lacaune ewes milked once or twice daily, with or without stripping. Pages 625-652 in Proc. Third Symp. Machine Milking of Small Ruminants, Valladolid, Spain.

Labussière, J. 1988. Review of physiological and anatomical factors influencing the milking ability of ewes and the organization of milking. Livest. Prod. Sci. 18:253-274.
Le Du, J. 1984. Etude de la productivité en salle de traite pour brebis: incidence du trayeur, de la race et de la taille d l'installation. Pages 303-325 in Proc. Third Symp. Machine Milking Small Ruminants, Valladolid, Spain.

Le Du, J., and Y. Dano. 1984. Equipement pour l'enregistrement automatique de la cinétique d'émission du lait. Pages 425-432 in Proc. Third Symp. Machine Milking Small Ruminants, Valladolid, Spain

Marnet, P. G., and B. C. McKusick. 2001. Regulation of milk ejection and milkability in small ruminants. Livest. Prod. Sci. 70:125-133.

McKusick, B. C., Y. M. Berger, and D. L. Thomas. 1999. Preliminary results: Effect of udder morphology on commercial milk production of East Friesian crossbred ewes. Pages 81-92 in Proc. Fifth Great Lakes Dairy Sheep Symp., Univ. Wisc.-Madison, Dept. Anim. Sci. and Univ. Vermont, Cntr. Sustainable Agric.

McKusick, B. C., D. L. Thomas, Y. M. Berger, and P. G. Marnet. 2002a. Effect of milking interval on alveolar versus cisternal milk accumulation, and milk production and composition in dairy ewes. J. Dairy Sci. 85:2197-2206.

McKusick, B. C., D. L. Thomas, J. E. Romero, and P. G. Marnet. 2002b. Effect of weaning system on milk composition and distribution of milk fat within the udder of East Friesian dairy ewes. J. Dairy Sci. 85:2521-2528.

Mein, G. A., M. R. Brown, and D. M. Williams. 1986. Effects on mastitis of overmilking in conjunction with pulsation failure. J. Dairy Res. 53:17-22.

Molina, M. P., C. Peris, A. Torres, L. Gallego, N. Fernandez, and M. Eitam. 1991. Supreson del repaso manual en el ordeno mecanico de ovejas de raza Manchega. Pages 638-654 in Proc. Fourth Intl. Symp. Machine Milking Small Ruminants, Kibbutz Shefayin, Israel.

Peterson, K. J. 1964. Mammary tissue injury resulting from improper machine milking. Am. J. Vet. Res. 25:1002.

Ricordeau, G., J. Martinet, and R. Denamur. 1963. Traite à la machine des brebis Préalpes du sud. Importance des différentes opérations de la traite. Ann. Zootech. 12:203-225.

Ricordeau, G., and J. Labussière. 1968. Traite à la machine des brebis. Conséquences de la suppression de l'égouttage manuel en fonction des caractéristiques de traite. Ann. Zootech. 17:245-256.

Sagi, R., and M. Morag. 1974. Udder conformation, milk yield and milk fractionation in the dairy ewe. Ann. Zootech. 23:185-192.

SAS User's Guide: Statistics, Version 8 Edition. 1999. SAS Inst., Inc., Cary, NC.

Thomas, D. L., Y. M. Berger, and B. C. McKusick. 2000. East Friesian germplasm: effects on milk production, lamb growth, and lamb survival. Proc. Am. Soc. Anim. Sci., 1999. Online. Available: http:// www.asas.org/jas/symposia/proceedings/0908.pdf.

Wilde, C. J., D. R. Blatchford, C. H. Knight, and M. Peaker. 1989. Metabolic adaptations in goat mammary tissue during long-term incomplete milking. J. Dairy Res. 56:7-15. 